\title{
Efficiency of metabolizable and net energy in growing bulls fed diets with maize silage
}

\section{S. Osięgłowski ${ }^{1}$, J.A. Strzetelski ${ }^{2}$, J. Kowalczyk ${ }^{3}$ and B. Niwińska ${ }^{2}$}

\author{
Research Institute of Animal Production, \\ ${ }^{1}$ Experimental Station \\ 64-122 Pawłowice, Poland \\ ${ }^{2}$ Department of Animal Nutrition \\ 32-083 Balice, Poland \\ ${ }^{3}$ The Kielanowski Institute of Animal Physiology and Nutrition, \\ Polish Academy of Sciences \\ 05-110 Jabłonna, Poland
}

(Received 17 October 2002; revised version 7 May 2003; accepted 15 July 2003)

\begin{abstract}
The experiment was carried out on 80 Black-and-White Lowland bulls with an average $75 \%(50.0$ to $87.5 \%$ ) HF blood share and average initial body weight (BW) of $175 \pm 5.0 \mathrm{~kg}$ fattened to $500 \pm 10$ $\mathrm{kg}$ final BW. The animals were divided into two groups of 40 bulls according to an analogue method based on BW and HF blood share, and fed rations consisting of maize silage and concentrate in an average ratio $64: 36 \%$ in DM for Group $\mathrm{N}$ fed according to the net energy system (IZ INRA, 2001) or $57: 43 \%$ in DM for Group M fed according to the metabolizable energy system (DLG, 1997). Within each group, four subgroups of 10 animals were formed and fattened at a different level of production providing daily BW gains (BWG), g: 800 (subgroup $\left.\mathrm{S}_{1}\right), 1000\left(\mathrm{~S}_{2}\right), 1200\left(\mathrm{~S}_{3}\right)$ and $1400\left(\mathrm{~S}_{4}\right)$. The (PDIE-PDIN)/UFV ratio in the ration for Group N was markedly smaller $(-1.84 \mathrm{~g} / \mathrm{UFV})$ than in group M $(+8.52 \mathrm{~g} / \mathrm{UFV})$. Daily BWG of animals of Group N in the respective subgroups were 1003, $1169,1266,1400 \mathrm{~g}$ and of Group M, 1109, 1170, 1308 and $1345 \mathrm{~g}$, but differences in BWG between the parallel subgroups of Groups $\mathrm{N}$ and $\mathrm{M}$ were statistically insignificant $(\mathrm{P}>0.05)$. Performance of animals fed according to both systems, net or metabolizable energy, did not differ markedly, however, formulation of the diet according to the IZ-INRA system compared with the DLG system resulted in superior balancing of energy and protein, as rations formulated according to ME contained markedly more concentrate and less roughage than according to the NE system.
\end{abstract}

KEY WORDS: fattening bulls, net energy, metabolizable energy, performance 


\section{INTRODUCTION}

Contemporary energy systems of ruminant feeding are based on Blaxter's (1962) experimental results demonstrating that metabolizable energy (ME) is the principle factor for energy evaluation in feeds for ruminants and their energy requirements. Meeting of energy requirement of animals depends on the degree of utilization of $\mathrm{ME}$ for net energy. The coefficient of ME utilization for net energy, taking into account maintenance and production requirements in fattened bulls, is positively correlated with metabolizability of gross energy and negatively with the level of production. All systems of ruminant feeding used in European countries take into account the efficiency of ME maintenance and production processes but only some of them formulate feed energy value as ME (AFRC, 1993; DLG, 1997) though they take into consideration the degree of its utilization for net energy (NE).

Feeding standards for ruminants accepted in Poland (IZ-INRA, 2001) adapted from the French system (INRA,1988) are based on ME content in individual feeds but take into account the efficiency of ME for NE and a production level of 1.5. However, they estimate the energy value of feeds and requirements of fattened bulls, similarly as the majority of energy systems (Van der Honig and Alderman, 1988), i.e. as NE, expressing it in terms of units for maintenance and meat production (UFV). The energy value expressed in UFV depends less on the level of production than that expressed in terms of net energy units (Gay and Micol, 1988).

Some authors investigating factors influencing net energy deposition are of the opinion that fattening cattle based on metabolizable energy is more justified as it allows predicting the results of production with higher precision (Gabel and Papstein, 1995a,b; Papstein et al., 1995). Our earlier study (Strzetelski et al., 1996) demonstrated that balancing rations for fattened bulls on the basis of ME according to ARC (1980) standards corresponds less to anticipated and obtained body weight gains than balancing according to INRA (1988) standards.

Accepting maize whole plant silage as the most effective roughage for fattened bulls and taking into consideration the recent results of investigations concerning the energy requirements of these animals, it seemed worthwhile to investigate the effect of differentiated energy content in the ration formulated in terms of $\mathrm{ME}$ or $\mathrm{NE}$ on the performance of fattening bulls.

\section{MATERIAL AND METHODS}

\section{Animals and feeding}

The experiment was carried out on 80 Black-and-White Lowland bulls with an average $75 \%$ (50.0 to $87.5 \%$ ) HF blood share and average initial weight of $175 \pm 5.0 \mathrm{~kg}$ 
fattened to $500 \pm 10 \mathrm{~kg}$ final body weight (BW). The animals were divided into two groups of 40 bulls according to an analogue method based on BW and HF blood share, and fattened on rations consisting of whole plant maize silage and concentrate in a ratio of $64: 36 \%$ in DM for group $\mathrm{N}$ fed according to NE or $53: 43 \%$ in DM for Group $\mathrm{N}$ fed according to ME. Within each group, four subgroups of 10 animals were formed and fattened at different levels of production providing daily BWG of, g: 800 (subgroup $\mathrm{S}_{1}$ ), $1000\left(\mathrm{~S}_{2}\right), 1200\left(\mathrm{~S}_{3}\right)$ and $1400\left(\mathrm{~S}_{4}\right)$. Initial and final BW were determined as mean weights before the morning feeding for two successive days. The animals were kept in individual stalls equipped with automatic drinking bowls and a slatted floor lined with rubber matting.

The bulls were given diets containing whole-plant maize silage, pelleted ( $\varnothing=$ $8 \mathrm{~mm}$ ) concentrate mixture (Table 1), and rapeseed oilmeal as a high-protein supplement. The maize silage and concentrate were given separately. The net energy (UFV) and protein value of feeds, components of the concentrate mixture and daily rations for group $\mathrm{N}$ were established according to IZ-INRA (2001) feeding standards using WINWAR ver. 1.6 (2000), WIMIX ver. 1.7 (2000) and INRAtion ver. 2.63 (1998/99) software, and for group M according to the DLG (1997) system using L. Mroczko metabolizable energy for fattening Ruminant Feeding ver. 2000 software.

Pellets of concentrate mixture were produced using Type H-10 Rofama-Rogoźno (Poland) equipment after treatment at $185^{\circ} \mathrm{C}$ and $6 \mathrm{~atm}$. for $1 \mathrm{sec}$ with steam. Pellet batches were stored for no longer than 3 months.

Before the experiment started, daily rations were established on the basis of the results of chemical analysis of feed components for Group N for each $30 \mathrm{~kg}$ BWG compartment using the IZ-INRA (2001) system and for Group M, $50 \mathrm{~kg}$ (DLG, 1997) ranges of BWG according to the software programs. Daily rations in particular groups were changed in different periods depending on daily BWG. The animals were fed once daily and feed refusals were collected daily. The BW of the animals was checked after each 30 days of the experimental period.

TABLE 1

Composition of concentrate mixture

\begin{tabular}{lc}
\hline Feeds & $\%$ \\
\hline Triticale grain, ground & 60.0 \\
Rye grain, ground & 16.0 \\
Rapeseed oilmeal & 7.0 \\
Soyabean oilmeal & 10.0 \\
Sugar beet molasses & 3.0 \\
Premix 3111 of Cargil firm $^{1}$ & 2.7 \\
CaHPO $_{4}$ & 1.0 \\
Binder & 0.3 \\
\hline
\end{tabular}

${ }^{1}$ in 1 kg: P 95, Ca 205, Mg 50, g; J 120, Zn 5000, Cu 1000, Fe 1000, Co 50, Se 20, mg: IU - vit. A 880000; vit. $\mathrm{D}_{3} 160000$; vit. E 1100 


\section{Analysis and calculation}

The chemical composition of feeds was determined according to AOAC (1990) methods. Maize silage was sampled and analyzed before and after each 30 days and other feeds after each 2 months of the experimental period. The results were subjected to statistical analysis according to the GLM procedure of SAS (1989) software.

The gross energy (GE) content in the concentrate mixture was calculated according to the equation given in INRA (1988) and in rapeseed oilmeal according to the equation given by Hoffman (1971). GE and ME contents in components of rations were estimated on the basis of Feed Composition Tables IZ-INRA (2001), these values and mean feed intake were used for calculation of GE and ME intake.

The content of net energy in daily rations was given in terms of UFV and for each group and subgroup of animals the following were calculated:

- metabolizability of rations, $\mathrm{q}=\mathrm{ME} / \mathrm{BE}$

- level of feeding, $\quad$ AFL $=[(\mathrm{MEm}+\mathrm{MEf}) / \mathrm{MEm}]$

- level of production $\quad \mathrm{APL}=[(\mathrm{NEm}+\mathrm{NEf}) / \mathrm{NEm}]$

- coefficient of ME for NE efficiency in processes of maintenance and production, $\mathrm{kmf}$

- accepting that ME for maintenance requirements in fattened bulls is $538 \mathrm{~kJ} /$ $\mathrm{BW}^{0.75}$ (DLG, 1977) and NE for maintenance requirements is $368 \mathrm{~kJ} / \mathrm{BW}^{0.75}$ (INRA 1988), the efficiency of ME and NE for production was also calculated for each group and subgroup.

\section{RESULTS}

The average content of nutrients and energy value of feeds for bulls is given in Table 2. In all subgroups, daily rations ingested by the bulls in Group M contained more concentrate $(\mathrm{P}<0.0001)$ and less maize silage $(\mathrm{P}<0.05)$ than consumed by the animals in Group N (Table 3). The animals of Group M ingested more dry matter and net energy (UFV) in successive subgroups and less crude protein, PDIN and PDIE, however, differences in means between the analogous subgroups of both groups did not always reach statistical significance $(\mathrm{P}<0.05)$. A similar dependence in mean values was also found between Groups N and M (Table 4). The animals of Group $\mathrm{M}$ ingested about $12 \%$ less maize silage daily, but about $14 \%$ more concentrate and $15 \%$ less crude protein and PDI $(\mathrm{P}<0.0001)$. Differences between the groups in DM and energy (UFV) intake appeared to be not significant statistically. 
OSIĘGŁOWSKI S. ET AL.

岌

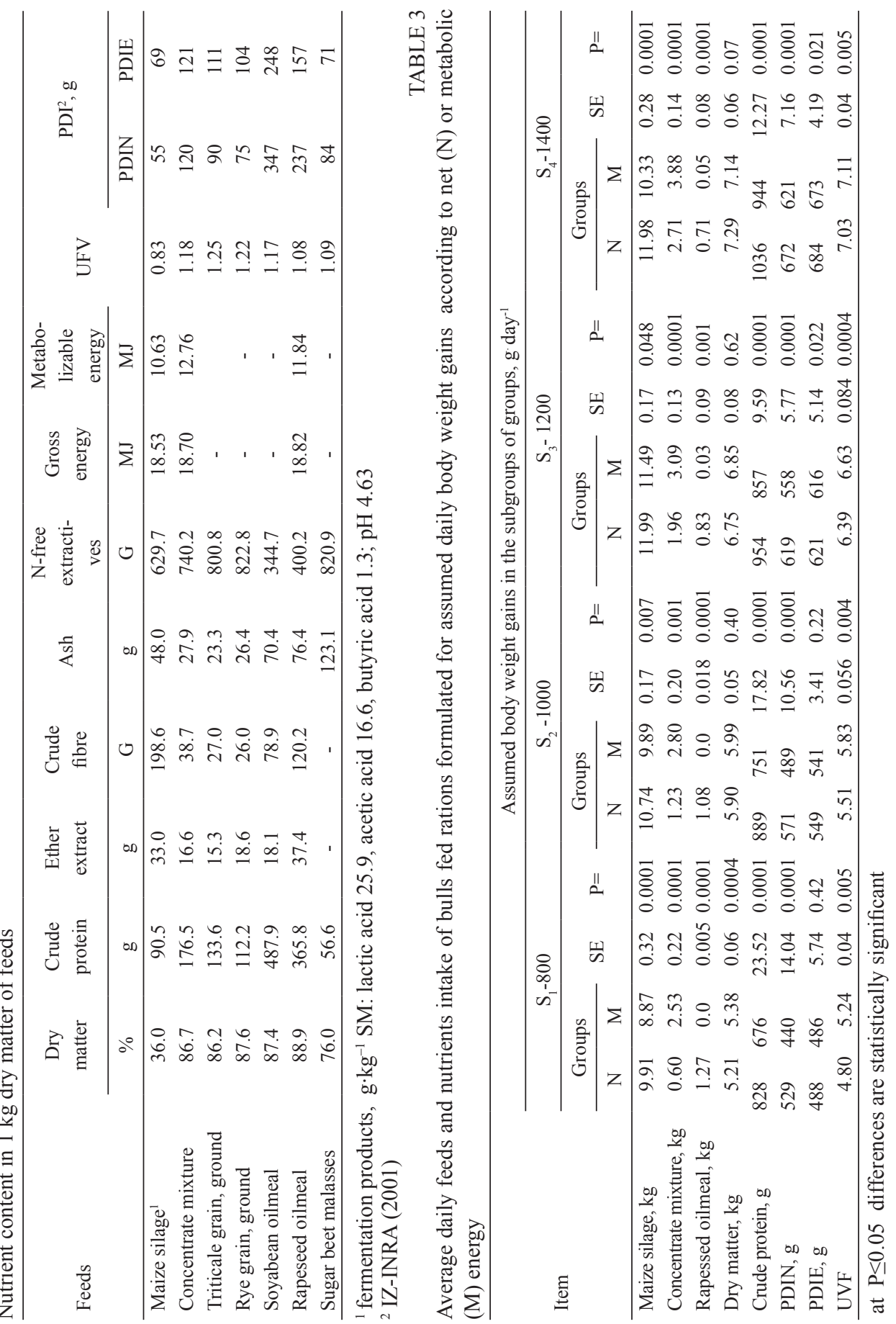


TABLE 4

Daily feed and nutrient intake in the groups of bulls fed according to net (N) and metabolic (M) energy

\begin{tabular}{lccccc}
\hline \multirow{2}{*}{ Item } & \multicolumn{2}{c}{ Groups } & & SE & $\mathrm{P}=$ \\
\cline { 2 - 3 } & $\mathrm{N}$ & $\mathrm{M}$ & & 0.16 & 0.08 \\
Maize silage, kg & 11.18 & 10.27 & & 0.07 & 0.0001 \\
Concentrate mixture, kg & 1.64 & 3.07 & 0.01 & 0.0001 \\
Rapeseed oilmeal, kg & 0.97 & 0.02 & & 0.09 & 0.86 \\
Dry matter, kg & 6.28 & 6.38 & & 13.35 & 0.0001 \\
Crude protein, g & 928 & 810 & 8.62 & 0.0001 \\
PDIN, g & 598 & 529 & 8.77 & 0.48 \\
PDIE, g & 587 & 582 & 0.08 & 0.03 \\
UFV & 5.98 & 6.22 & & \\
\hline
\end{tabular}

at $\mathrm{P}<0.05$ differences are statistically significant

The ratio of maize silage to concentrate in the diet for Group $\mathrm{N}$ averaged 64 : $36 \%$ in DM and gradually decreased with increasing production level from 68 : $32 \%$ (subgroup $\mathrm{S}_{1}-800$ ) to $59: 41 \%$ in DM (subgroup $\mathrm{S}_{4}-1400$ ), but in Group $\mathrm{M}$ this ratio was averaged $57: 43 \%$ in DM and was similar in the first three subgroups (59:41\% in DM) and equalled $52: 48 \%$ in DM in subgroup $\mathrm{S}_{4}-1400$.

The average content of GE in rations for bulls of both groups was similar $(117.8 \pm 0.5$ MJ) but increased in successive subgroups from $98.4 \pm 1.5 \mathrm{MJ}$ to $133.9 \pm 1.6 \mathrm{MJ}$. The content of ME in rations for group $\mathrm{N}$ was $71.0 \mathrm{MJ}$ and increased from 57.9 MJ in subgroup $\mathrm{S}_{1}-800$ to $83.2 \mathrm{MJ}$ in subgroup $\mathrm{S}_{4}-1400$. In Group $\mathrm{M}$ the respective values were: $73.4 \mathrm{MJ}$ and increased from 61.9 do $83.0 \mathrm{MJ}$. In both groups, as average daily BWG increased, the metabolizabilty $(\mathrm{q}=\mathrm{ME} / \mathrm{GE})$ of rations increased somewhat as well. The average value of q was slightly higher in ration $\mathrm{M}(0.62)$ than $\mathrm{N}(0.60)$. The average feeding level (AFL) gradually increased in subgroups from 1.4 (Group N) or 1.5 (Group M) to 2.0 in both groups, with respective average values of 1.7 and 1.8. The increase of daily BWG in subgroups was parallel to the increase in production level (APL), from 1.2 (Group N) or 1.3 (Group M) to 1.7 in both groups and averaged 1.5 and 1.6, respectively. The decline in the efficiency coefficient of ME for NE $(\mathrm{kmf})$ gradually diminished in the subgroups of both groups: from 0.67 in $\mathrm{N}$ and 0.66 in $\mathrm{M}$ group to 0.60 and 0.61 , respectively. Average $\mathrm{kmf}$ values for these groups were $0.62(\mathrm{~N})$ and $0.63(\mathrm{M})$. The average value of $\mathrm{BW}^{0.75}$ for both groups was $78.8 \mathrm{~kg}$. The efficiency of ME in production processes varied in the successive subgroups from 27 (Group N) or 32 (Group M) to $49 \%$ in both groups; the average for the respective groups was 41 and $42 \%$. Efficiency of NE for production was on average about 3 percentage units higher in Group N (35\%) than in Group M (32\%) and increased as daily BWG increased in successive subgroups from 16 to $42 \%$ when feeding bulls according NE standards and from 22 to $42 \%$ in animals fed according requirements for $\mathrm{ME}$. The biggest differences in $\mathrm{NE}$ efficiency for production processes between groups $\mathrm{N}$ and 


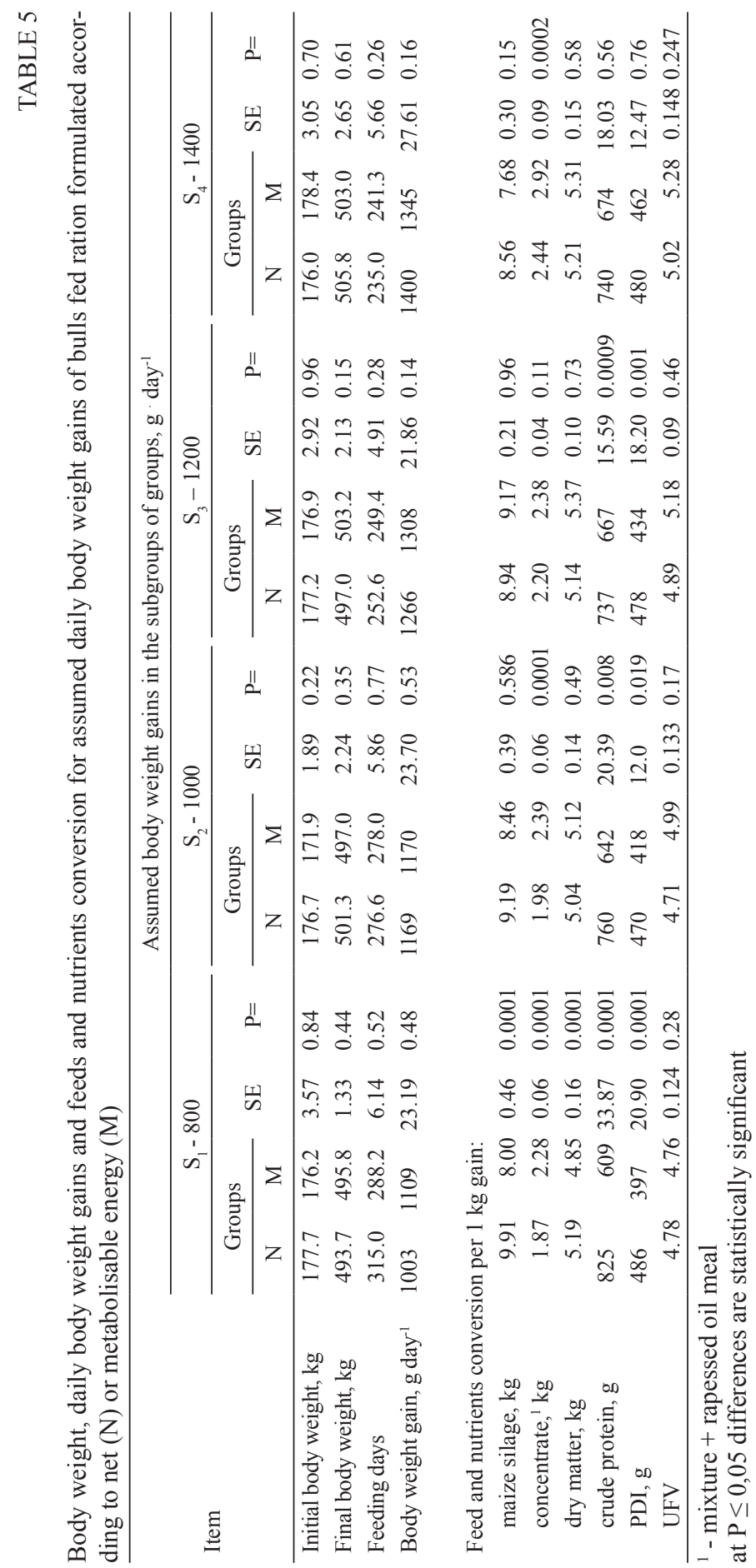


$M$ was found between analogous groups $S_{1}-800$. The efficiency of NE for production of $1 \mathrm{~kg} \mathrm{BW}{ }^{0.75}$ in this subgroup of group $\mathrm{M}$ was about 7 percentage units higher.

The (PDIE-PDIN)/UFV ratio in the ration for Group N was markedly smaller $(-1.84 \mathrm{~g} / \mathrm{UFV})$ than in group $\mathrm{M}(+8.52 \mathrm{~g} / \mathrm{UFV})$ and in successive subgroups of Group N it increased starting from $-8,54$ to $+1.71 \mathrm{~g} / \mathrm{UFV}$. In Group M, it was on a similar level in all subgroups (8.78 to $7.31 \mathrm{~g} / \mathrm{UFV}$ ).

Daily BWG of animals in Group N in respective subgroups equaled 1003, 1169, 1266, $1400 \mathrm{~g}$ and in Group M 1109, 1170, 1308 and $1345 \mathrm{~g}$. Differences between analogous subgroups in average daily BWG were not significant $(\mathrm{P}>0.05)$, although in some subgroups, the bulls in Group $\mathrm{M}$ grew faster than in Group $\mathrm{N}$ (Table 5). BWG of bulls of Group M (subgroup $S_{1}-800$ and $S_{3}-1200$ ) were 10 and $5 \%$, respectively, higher than in Group N. Intake of concentrate and maize silage, crude protein and PDI per kilogram BWG was significantly lower $(\mathrm{P}<0.0001)$ in all subgroups of Group $\mathrm{N}$ than Group $\mathrm{M}$, but the differences in DM and energy (UFV) intake between groups were not statistically significant $(\mathrm{P}>0.05)$, although a slight tendency towards better utilization in subgroup $S_{1}-800$ of group $M$ and worse utilization in the remaining subgroups developed as compared with the subgroups of Group N.

Daily BWG in subgroups $\mathrm{S}_{1}-800, \mathrm{~S}_{2}-1000$ and $\mathrm{S}_{3}-1200$ of group $\mathrm{N}$ were higher than assumed by about 20,15, and 5\% and in Group $\mathrm{M}$ by 28,15 and $8 \%$, respectively. Bulls of subgroup $\mathrm{S}_{4}-1400$ gained as was assumed.

A tendency towards better BWG in the bulls of Group M than in Group N during the whole experimental period (Table 6, Figure 1) was marked.

TABLE 6

Body weight, daily body weight gains, feed and nutrients conversion in groups of bulls fed according to net (NE) or metabolizable (ME) energy

\begin{tabular}{|c|c|c|c|c|}
\hline \multirow{2}{*}{ Item } & \multicolumn{2}{|c|}{ Groups } & \multirow{2}{*}{$\mathrm{SE}$} & \multirow{2}{*}{$\mathrm{P}=$} \\
\hline & $\mathrm{N}$ & $\mathrm{M}$ & & \\
\hline Initial body weight, $\mathrm{kg}$ & 176.9 & 176.0 & 1.47 & 0.68 \\
\hline Final body weight, kg & 499.4 & 499.8 & 1.11 & 0.86 \\
\hline Feeding days & 267.0 & 262.7 & 3.89 & 0.43 \\
\hline Body weight gain, $\mathrm{g} \mathrm{day}^{-1}$ & 1208 & 1232 & 17.92 & 0.44 \\
\hline \multicolumn{5}{|c|}{ Feed and nutrients conversion per $1 \mathrm{~kg}$ of gain: } \\
\hline maize silage, $\mathrm{kg}$ & 9.25 & 8.35 & 0.16 & 0.0001 \\
\hline concentrate, $\mathrm{kg}$ & 2.16 & 2.50 & 0.04 & 0.0001 \\
\hline dry matter, $\mathrm{kg}$ & 5.20 & 5.17 & 0.07 & 0.32 \\
\hline crude protein, $\mathrm{g}$ & 768 & 652 & 11.61 & 0.0001 \\
\hline PDI, g & 486 & 428 & 0.06 & 0.0001 \\
\hline UFV & 4.95 & 5.05 & 0.06 & 0.68 \\
\hline
\end{tabular}

at $\mathrm{P} \leq 0.05$ differences are statistically significant 


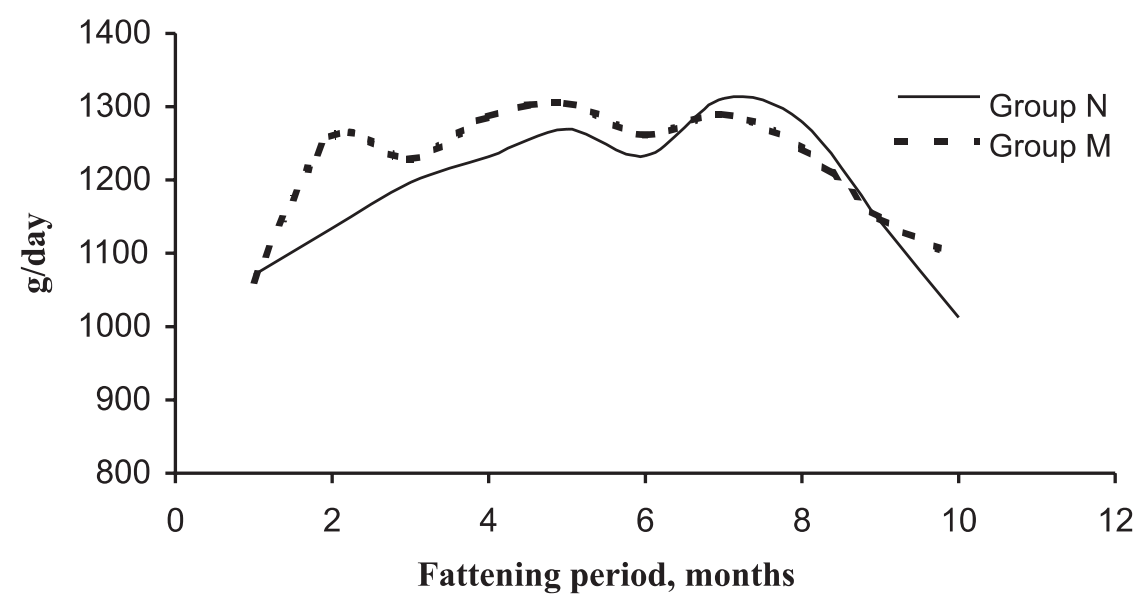

Figure 1. Changes in daily body weight gain in fattening period

\section{DISCUSSION}

The assumed and achieved daily BWG in analogous subgroups $\mathrm{S}_{1}-800, \mathrm{~S}_{2}-1000$, $\mathrm{S}_{3}-1200$ in both groups indicate that both feeding systems for bulls, DLG (1997) and IZ-INRA (2001), overestimated the requirements of fattened bulls. Higher than assumed daily BWG might be caused by higher than designed nutrient intake. The proportion of maize silage and concentrate in daily rations for animals in the respective ranges of $\mathrm{BW}$ were established assuming that the composition of rations would be similar throughout the experimental period. However, chemical analysis demonstrated that the nutrient content in the ration was variable over the course of the experiment, especially in relation to maize silage, as its initial DM content of $28 \%$ increased markedly with time to $41 \%$. In both groups, as BWG increased in successive subgroups, the difference between the expected and obtained gains declined. It seems that at a higher rate of BWG (1200 - $1400 \mathrm{~g} /$ day) the supply of nutrients did not exceed or only slightly exceeded the requirement for the assumed BWG.

The gradual increase of GE metabolizability of rations (q) and AFL and APL values as the BWG increased in consecutive subgroups of both groups, accompanied by a parallel decrease of the kmf coefficient value, is consistent with the assumption of both bull fattening systems applied in the experiment (INRA, 1978; Geay et al., 1987; Gabel and Papstein, 1995b).

Slightly lower metabolizability of rations and kmf coefficients in Group M compared with Group N suggest that bulls fed according to ME requirement should grow faster than those fed rations formulated according to the NE system.

Indeed, in bulls of Group M, particularly in some subgroups, a tendency towards higher BWG was marked compared with group $\mathrm{N}$, but these differences did not 
reach statistical significance $(\mathrm{P}>0.05)$. It is possible that in respect to the wider ratio of concentrate to roughage in Group M compared with Group N, the negative interaction of concentrate $x$ roughage was marked more strongly. This could decrease the real energy value of the ration, which could limit the animal's rate of growth.

Lack of significant differences in daily BWG between bulls fed according to the metabolizable energy (DLG, 1997) and UFV (IZ-INRA, 2001) systems and, at the same time, better utilization of ME and NE per $\mathrm{kg} \mathrm{BW}^{0.75}$ and a wider ratio of (PDIE - PDIN)/UFV in Group M than N suggests that BWG in this group contained more fat than protein. The utilization $\mathrm{ME} / \mathrm{kg} \mathrm{BW}^{0.75}$ (Gabel and Papstein, 1995b) obtained in both groups was similar to the value that can be obtained determining the requirement for ME according to DLG (1997) standards, accepting the average $\mathrm{BW}^{0.75}$ as $78.8 \mathrm{~kg}$ and daily BWG $1200 \mathrm{~g} /$ day in both groups. The INRA (1988) system assumes a maintenance requirement for bulls of dairy breeds $502 \mathrm{~kJ}$ ME/ $\mathrm{kg} \mathrm{BW}^{0.75}$ and beef breads $577 \mathrm{~kJ} \mathrm{ME} / \mathrm{kg} \mathrm{BW}^{0.75}$ and on such assumptions, ME efficiency for production is about 4 percentage units higher in both groups.

It is difficult to state unequivocally, based on the production results obtained, which of these values are more appropriate for fattened bulls of dairy cattle breeds raised in Poland. It was demonstrated by numerous authors (NRC, 2000) that maintenance requirements depend on many factors such as age, body weight, breed, genetic potential influencing the rate of growth and also maintenance conditions. ME for maintenance requirements for fattened bulls according to NRC (2000) ranges, depending on the these factors, from 443 to $528 \mathrm{MJ} / \mathrm{kg} \mathrm{BW}^{0.75}$. In our experiment, however, ME for maintenance requirements calculated according to the equations given in AFRC (1993) standards taking into account average matabolizability (q) of rations fed in Groups $\mathrm{N}$ and $\mathrm{M}$ was on average $547 \pm 5 \mathrm{~kJ} / \mathrm{kg} \mathrm{BW}^{0.75}$.

The decrease of differences between designed daily BWG and that obtained in analogous subgroups of both groups with faster growth of bulls suggests that at higher BWG, above $1200 \mathrm{~g} /$ day, rations formulated according to requirements for $\mathrm{ME}$ as well as NE gave a similar production effect.

\section{CONCLUSIONS}

In summarising the results of the experiment it can be concluded that the performance of fattened bulls of dairy breed was similar for both ME and NE feeding systems. However, formulating rations according to the IZ-INRA(2001) system as compared with the DLG (1997) system allows achieving a better balance of protein and energy in the diets. Diets formulated according to the ME system contain more concentrate and less roughage than the NE system. Both systems can be used in practice for fattening bulls, but their usefulness for the farmer depends, first of all, on the costs of concentrate and roughages. 


\section{REFERENCES}

AFRC, 1993. Energy and Protein Requirements of Ruminants.G.Alderman, B.R. Cottrill (Editors). CAB International, Wallingford (UK), pp. 3, 23-24

ARC, 1980. Agricultural Research Council. The Nutrient Requirements of Ruminant Livestock. Commonwealth Agricultural Boreaux, Farham Royal, Slough (England), pp. 351

AOAC, 1990. Association of Official Analytical Chemists, Official Methods of Analysis. $15^{\text {th }}$ Edition. Arlington, VA

Blaxter K.L., 1962. Energy Metabolism of Ruminants. Hutchinson Scientific Technical, London

DLG-Futterwerttabellen-Wiederkauer, 1997. 7.erweiterte und überarbeitete Auflage. DLG-Verlag, Frankfurt am Main

Gabel M., Papstein I., 1995a. Untersuchungen zur Leerkörpermassezunahme, zum Protein-, Fett- und Energieansatz sowie zur Verwertung der Umsetzbaren Energie für den Energieansatz bei Schwarzbunten Bullen. 2. Mitteilung. Protein-, Fett- und Energieansatz. Arch. Anim. Nutr. 48, 271-286

Gabel M., Papstein I., 1995b. Untersuchungen zur Leerkörpermassezunahme, zum Protein-, Fettund Energieansatz sowie zur Verwertung der umsetzbaren Energie für den Energieansatz bei Schwarzbunten Bullen (SMR) 3. Mitteilung. Beziehungen zwischen dem Energieansatz und dem Verzehr an umzetbarer Energie. Arch. Anim. Nutr. 48, 287-301

Geay Y., Micol D., 1988. Growing and finishing cattle. In: R. Jarrige (Editor). Ruminant Nutrition. Recommended Allowances and Feed Tables. INRA, John Libbey, Eurotext London-Paris, pp. 121-152

Geay Y., Micol D., Robelin J., Berge Ph., Maltere C., Jailler Rd., 1987. Recomandations alimentaires pour en croissance et a l'engrais. Bull. Tech. C.R.Z.V. Theix. INRA 70, 173-183

Hoffmann L., Schiemann R., Jentsch W., 1971. Energetische Verwertung der Nährstoffe in Futter Rationen. In: Energetisch Futterbewertung und Energienormen. VEB, Dte. Landw. Verlag, Berlin, pp. 118-167

INRA, 1978. Principes de la Nutrition et de l'Alimentation. Besoins Alimentaires des Animaux, Valeur Nutritive des Aliments. R. Jarrige (Editor), pp. 62, 78-79

INRA, 1988. Ruminant Nutrition. Recomended Allowances and Feed Tables. R Jarrige (Editor). John Libbeey Eurotekxt, London - Paris, pp. 25-27, 124, 198-200

IZ-INRA, 2001. Standards for Cattle, Sheep and Goat Nutrition (in Polish). Research Institute of Animal Production, Kraków (Poland)

NRC, 2000. Nutrient Requirements of Beef Cattle. National Academy Press, Washington, DC, pp. 6-7

Papstein I., Gabel M., Papstein H.J., 1995. Untersuchungen zur Leerkörpermassezunahme, zum Protein-, Fett- und Energieansatz sowie zur Verwertung der umsetzbaren Energie für den Energieansatz bei Schwarzbunten Bullen (SMR) 1. Mitteilung-Leerköpermassezunahme. Arch. Anim. Nutr. 48, 201-210

Strzetelski J.A., Wieczorek Z., Krawczyk K., Stasiniewicz T., Maciaszek K., Kraszewski J., 1996. Young bulls fattening based on various energy and protein standardisation systems (in Polish). Rocz. Nauk. Zoot. 23, 113-129

Van der HoningY., Alderman G., 1988. Feed evaluation and nutritional requirements. 2. Ruminants. Livest. Prod. Sci., Special Issue, 19, 217-278 


\section{STRESZCZENIE}

\section{Efektywność energii metabolicznej i energii netto w opasie buhajków żywionych kiszonką z kukurydzy}

Doświadczenie przeprowadzono na 80 buhajkach rasy nizinnej czarno-białej ze średnim 75\% $(50,0$ to $87,5 \%$ ) dolewem krwi HF i początkowej masie ciała $175 \pm 5,0 \mathrm{~kg}$ opasanych do $500 \pm 10 \mathrm{~kg}$. Buhajki podzielono metodą analogów na dwie grupy, po 40, i żywiono według systemu energii metabolicznej (Grupa M) lub energii netto (Grupa N). W każdej grupie utworzono 4 podgrupy po 10 zwierząt, które opasano zakładając różne poziomy produkcji przewidujące przyrosty masy ciała: (g/dzień): 800 (podgrupa $\left.\mathrm{S}_{1}\right), 1000\left(\mathrm{~S}_{2}\right), 1200\left(\mathrm{~S}_{3}\right)$ lub $1400\left(\mathrm{~S}_{4}\right)$. Zwierzęta trzymano na indywidualnych stanowiskach wyścielonych gumowymi matami z automatycznymi poidłami i ważono je co miesiąc przed rannym karmieniem przez dwa kolejne dni. Dzienne dawki kiszonki z kukurydzy i paszy treściwej oraz śruty rzepakowej, jako dodatku uzupełniającego białko, w poszczególnych przedziałach wagowych Grupy M (30 kg) ułożono według systemu IZ-INRA (2001), a dla Grupy N (50 $\mathrm{kg}$ ) według systemu DLG (1997). Stosunek kiszonki z kukurydzy do paszy treściwej w Grupie M wynosił średnio 57:43\% w s.m., w Grupie N 64:36\% w s.m. Dzienne przyrosty masy ciała buhajków w kolejnych podgrupach wynosiły odpowiednio, g/dzień: 1003, 1169, 1266, 1400, w Grupie M: 1109, 1170, 1308 i 1345. Stosunek różnicy (PDIE-PDIN)/UFV w Grupie N był wyraźnie mniejszy (-1,84 g/UFV) niż w Grupie M (+8,52 g/UFV).

Między analogicznymi podgrupami obydwóch grup nie stwierdzono statystycznie istotnych różnic $(\mathrm{P}>0,05) \mathrm{w}$ dziennych przyrostach masy ciała. Wyniki produkcyjne opasanych buhajków były podobne zarówno przy skarmianiu dawek pokarmowych układanych według systemu ME lub NE.

Układanie dawek pokarmowych zgodnie z zaleceniami systemu IZ-INRA pozwoliło na lepsze, w porównaniu z normami DLG, ich zbilansowanie pod względem energii i białka. Dawki pokarmowe bilansowane według ME w porównaniu z dawkami bilansowanymi według NE zawierały znacznie więcej paszy treściwej, a mniej objętościowej. 